\title{
Nutritional, physicochemical, antimicrobial and DPPH free radical scavenging potential of the biotech and conventional hybrids of seeds and seed oils from Gossypium hirsutum L.
}

\author{
Fazia Ghaffar ${ }^{1 *}$, Ikhtiar Khan ${ }^{2}$, Hamidullah $\mathrm{Shah}^{3}$ and Karishma \\ Iqbal $^{2}$
}

1. Department of Food \& Nutrition Sciences, College of Home Economics, University of Peshawar, KPKPakistan

2. Institute of Chemical Sciences, University of Peshawar, KPK-Pakistan

3. Department of Agricultural Chemistry, Faculty of Nutrition Sciences, KPK Agriculture University, PeshawarPakistan

*Corresponding author's email: faziaghaffar@upesh.edu.pk

Citation

Fazia Ghaffar, Ikhtiar Khan, Hamidullah Shah and Karishma Iqbal. Nutritional, physicochemical, antimicrobial and DPPH free radical scavenging potential of the biotech and conventional hybrids of seeds and seed oils from Gossypium hirsutum L. Pure and Applied Biology. Vol. 7, Issue 2, pp765-774. http://dx.doi.org/10.19045/bspab.2018.70095

\begin{tabular}{llll}
\hline \hline Received: 11/03/2018 & Revised: 01/06/2018 & Accepted: 05/06/2018 & Online First: 28/06/2018 \\
\hline
\end{tabular}

\section{Abstract}

This comparative study investigated the differences in the proximate and mineral composition of seed and fatty acid profiles, physiochemical, antimicrobial properties, and antioxidant characteristics of seed oils of FH-942 (NBt) and MNH-886 (Bt) of Gossypium Hirsutum (upland cotton). Proximate analysis of seeds of both the hybrids showed ash content (7.74\% conventional \& $6.69 \%$ BT), crude fat (14.4\% conventional \& $12.2 \%$ BT), crude protein (29.9\% conventional \& $28.49 \%$ BT) and organic compounds like alkaloids of the conventional hybrid being comparatively better than the biotech hybrid. The carbohydrates and crude fiber of the Bt variety were on the higher side. The Bt genotype had comparatively higher content of calcium, copper and manganese. The physical properties of the crude oil showed density $(\mathrm{g} / \mathrm{ml}) 1.046 \& 1.119$, specific gravity $0.981 \& 1.043$, and refractive index $1.467 \& 1.468$ for conventional and biotech variety respectively. Chemical properties of the crude oils indicated iodine value (conventional 101.2, BT $95.2 \mathrm{~g}$ of $\mathrm{I} 2 / 100 \mathrm{~g}$ of oil), Saponification value (conventional 189.28, BT $175.30 \mathrm{mg}$ of $\mathrm{KOH} / \mathrm{g}$ oil) of the conventional hybrid was better than the biotech hybrid. Fatty acid composition from both genotypes showed insignificant variations except for linoleic acid and linolenic acid being significantly higher in MNH-886. Crude oil of both the hybrids showed lower antibacterial activity against streptomycin and good antifungal potential. Oils of both the hybrids also showed good antioxidant potential in DPPH free radical scavenging indicating greater potentials of both varieties to be used as an edible oil $\&$ in the manufacturing of various industrial products.

Keywords: Antibacterial activity; Antifungal activity; Antioxidant potential; Fatty acids composition; Physico-chemical properties; Proximate compositio

Introduction

Belonging to the Malvaceae family and tribe of Gossypieae, Gossypium (cotton) grow naturally as a perennial shrub or tree. However for commercial purposes it is grown as an annual crop. Gossypium 
hirsutum L. (upland cotton) is a major cash crop known to be the source of world's most important textile fiber, the second best source of plant protein after soybean, and the fifth oil producing plant. Cotton fiber is used to make a number of textile products. In addition to textile industry cottonseed is used to produce oil which after refining can be used like any other vegetable oil. Traditionally four major species of cotton are being grown: hirsutum, barbadense, arboretum, and herbaceum around the world [1].

Cotton accounts for 8.2 percent of the value added in agriculture and about $3.2 \%$ to GDP; around two thirds of Pakistani export earnings are from the cotton madeup textiles which in turn adds about \$ 2.5 billion to the national economy. While hundreds of ginning factories and textile mills in the country heavily depend upon cotton, life of millions of farmers is dependent upon this crop [2]. In Pakistan nearly all of the cottonseed oil is processed commercially to be utilized for edible purposes .It contribute $70 \%$ in the Pakistani edible oil production as compared to $13 \%$ sunflower, $11 \%$ rapeseed/mustard seed, and 5.6\% Canola [3]. It has high level of antioxidantVitamin E- that contributes to its long life in the cooking and on the shelf. This processed cottonseed oil is the fifth leading vegetable oil in the world. Cotton seed oil is generally considered as healthy vegetable oil. It is cholesterol free and hence termed as "Heart oil". Cotton seed meal which is left after oil extraction is used as a source of fodder protein in livestock industry [4]. Constituting nearly half of a seed's weight the meal contains $23 \%$ high biological value proteins [2].

A number of different cotton varieties have been developed from the conventional varieties. These Bacillus thuringiensus (BT) cotton are variety of cotton genetically modified that confers resistance to boll worm complex. These proteins have specific insecticidal activity but are nontoxic humans and other vertebrates [5-7]. Year 2012 was third year of commercialization of $\mathrm{Bt}$ Cotton in Pakistan. At an adoption rate of $82 \%$ on the total 3.4 million hectares of land was used for cotton based on the assumption that this surplus production in 2012-2013 of 15.5 million bales will allow increased cotton exports by $77 \%$ [2]. Cotton cultivars (both $\mathrm{Bt}$ and conventional) are substantially similar in chemical composition however such type of investigations were being not done previously in Pakistan. The current study aimed to compare nutritional composition of cottonseed and physiochemical, and antimicrobial activities of one biotech variety against one conventional variety as a control.

\section{Materials and methods}

Two hybrids of cottonseeds FH-942 (CLCUV- Heat tolerant, conventional) and MNH-886 (FH-207×MNH770×Bollgard1 , Biotech) were obtained from the seed unit of Cotton Research Institute, Ayub Research Institute, Faisalabad, Pakistan. The samples were thoroughly cleaned. Seed were ground and kept in dark dry conditions.

\section{Proximate composition and mineral content determination}

After oil extraction the seed cake /residue/flour samples were tested for proximate and elemental composition. By using AOAC official methods, total protein content of the seed cake was estimated by a micro Kjeldhal apparatus. Crude oil was estimated by Soxhlet method while crude fiber and ash contents were determined by the AOAC official methods [8, 9]. For minerals analysis samples were first subjected to acid digestion and later were analyzed by atomic absorption spectrophotometer (AAS) methods [10].

\section{Oil extraction}

To determine percent oil seeds were extracted with n-hexane, chloroform and petroleum ether. Seed were soaked separately for 24 hours and the extracts were then concentrated with rotary 
evaporator under reduced pressure at 40$60^{\circ} \mathrm{C}$.

\section{Physiochemical tests}

Based on the methods described by the association of Official Analytical Chemists both of oil samples were tested for refractive index, specific gravity, viscosity, iodine value, saponification value, peroxide value, total acid number and free fatty acids value [9].

Fatty acids analysis

\section{Preparation of fames}

About 25-40 mg of oil sample were weighed in FAMEs tubes and $1.5 \mathrm{ml}$ methanolic Sodium hydroxide $(0.5 \mathrm{~N})$ was added. The tubes were Stoppard with screw capes. The mixture was heated in a boiling water bath for 05 minutes. Tubes were cooled to room temperature and 2.5 $\mathrm{ml} \mathrm{BF}_{3}(10 \%$ in $\mathrm{MeOH})$ was added. Tubes were again heated in boiling $\mathrm{H}_{2} \mathrm{O}$ for half an hour. Cooled at room temperature \& and $5 \mathrm{ml}$ brine solution $+1 \mathrm{ml} \mathrm{n}$-hexane was added. The tubes were shaken vigorously on vortex and then allowed the layers were allowed separate. The upper (n- hexane) layer was taken through pasture pipette. For GCMS analysis about $1 \mathrm{ml} \mathrm{n}$-hexane was added again to repeat the above steps to separate the hexane layer. The volume was adjusted to $2 \mathrm{ml}$, filtered through $45 \mu \mathrm{m}$ membrane filter and transferred to $\mathrm{GC}$ vial for injection into GC-MS.

\section{Identification of fatty acids by GC-MS}

The methyl esters of the oil were analyzed for the respective fatty acid composition by Gas Chromatography Mass Spectrometry. The equipment used for this purpose was Shimadzu GC-MS- QP 2010 Plus using a capillary column TRB FRAP (30 $\mathrm{m} \times 0.25 \mathrm{~mm}$ i.d). The temperature programming of the column oven was set as $50{ }^{\circ} \mathrm{C}-220{ }^{\circ} \mathrm{C}$ with rise of $5{ }^{\circ} \mathrm{C} / \mathrm{min}$. Helium was used as the carrier gas and its total flow was adjusted to $77.1 \mathrm{ml} / \mathrm{min}$ while column flow was $3.29 \mathrm{ml} / \mathrm{min}$ at split ratio of 20.0. The temperatures of injector, interface and ion source were set at $240{ }^{\circ} \mathrm{C}, \quad 240{ }^{\circ} \mathrm{C}$ and, $250{ }^{\circ} \mathrm{C}$ respectively. The peaks were identified by comparison of their retention time with those of the standard methyl esters (FAMEs standard mix, 37 components, Sigma Aldrich) analyzed under the same conditions.

\section{Antimicrobial assay}

The test for susceptibility was done using agar Well Diffusion method [11]. Two stains of gram positive bacteria (Staphylococcus aureus, and Bacillus subtilis) and one gram-negative bacterium (Klebsiella Pneumonia) against streptomycin as a standard. Antifungal effect of the oils against three fungal strains (Alternaria solania, Aspergilus niger and Aspergillus flavus) were determined by Tube Dilution methods using miconazole as a standard [7].

Antioxidant activity by 2, 2-Diphenyl-1Picrylhydrazyl (DPPH) free radical scavenging methods

Antioxidant activity was measured from the bleaching of methanol solution of 2, 2diphenyl-1-picrylhyrazyl (DPPH) using optima UV-Visible Spectrophotometer. DPPH radical scavenging activity was performed by following the method of Rauf et al [11]. About 25mg of oil was dissolved in distilled methanol and was diluted up to $50 \mathrm{~mL}$. From the stock solution 10, 20,40,60,80,100 $\mathrm{mg} / \mathrm{ml}$ dilutions were prepared. Of each solution 5 $\mathrm{mL}$ was taken in a test tube to which $1 \mathrm{~mL}$ of $0.01 \mathrm{M}$ of DPPH solution was added. They were kept in a dark for test minutes along a control (5 methanol+ $1 \mathrm{~mL} \mathrm{DPPH}$ solution). After the incubation for 30 minutes the antioxidant activity was measured by using Optima U-V- Visible Spectrophotometer at wave length of 517 $\mathrm{nm}$. The experiments were performed in three replicates. Quercetin was taken as a standard for the purpose of comparison. Percent radical scavenging activity was calculated as:

$\% \mathrm{DPPH}=$ Control absorbance- Extract absorbance $\times 100$ / Control absorbance. 


\section{Statistical analysis}

Data collected from the triplicate analyses was analyzed for means, standard deviations and one way ANOVA at $\mathrm{P}=<$ 0.05 level of significance wherever needed.

\section{Results}

Cotton as "white gold" monopolizes global trade market as a cash crop. Cotton plant give four main important products-fibers, linters, seed oil, and seed cake. Proximate composition of both seed cakes (Table 1) showed that percent moisture of conventional variety was $16.53 \%$ and that of Biotech variety was $8.67 \%$ percent ash content of the conventional variety (7.74 $\%)$ was higher than the biotech variety
(6.69\%). Crude protein content of the conventional variety was $29.98 \%$ while that of Biotech variety was $28.49 \%$ the results of crude fat $(14.4,12.2)$, and total alkaloids $(12.14,10.96)$ content of the conventional variety were higher than $\mathrm{Bt}$ variety, However crude fiber content (11.79\% and $15.84 \%)$ and percent pectin (3.7 and 4.7) of the Bt variety were higher than conventional $\mathrm{FH}-942$ hybrid of the cotton. Results of the mineral concentrations showed that indigenous variety had significantly higher concentrations of iron and zinc while $\mathrm{Bt}$ hybrid contained much higher value of calcium, phosphorus and manganese.

Table 1. Proximate composition of cotton seeds

\begin{tabular}{|c|c|c|}
\hline Properties & FH-942 & MNH-886 \\
\hline & Proximate Values (g/100g) \\
\hline Moisture (\%) & $16.53 \pm 0.02$ & $8.67 \pm 0.91$ \\
\hline Ash (\%) & $7.74 \pm 0.82$ & $6.69 \pm 0.05$ \\
\hline Crude protein (\%) & $29.98 \pm 0.09$ & $28.49 \pm 0.05$ \\
\hline Crude fat (\%) & $14.4 \pm 1.04$ & $12.2 \pm 0.05^{*}$ \\
\hline Crude fiber (\%) & $11.79 \pm 0.71$ & $15.84 \pm 2.13^{*}$ \\
\hline Pectin (\%) & $3.7 \pm 0.84$ & $4.7 \pm 1.02^{*}$ \\
\hline Total alkaloids & $12.140 \pm 0.56$ & $10.96 \pm 0.91^{*}$ \\
\hline Calcium & $0.445 \pm 0.006$ & $0.932 \pm 0.04^{*}$ \\
\hline Phosphorus & $1.154 \pm 0.04$ & $1.862 \pm 0.007^{*}$ \\
\hline Copper & $13.74 \pm 0.003$ & $13.04 \pm 0.005$ \\
\hline Iron & $129.62 \pm 0.02$ & $111.54 \pm 0.03^{*}$ \\
\hline Zinc & $67.08 \pm 0.02$ & $62.53 \pm 0.06$ \\
\hline Manganese & $12.2 \pm 0.04$ & $15.87 \pm 0.02^{*}$ \\
\hline
\end{tabular}

*values are different significantly at $\mathrm{P} \leq 0.05$

Results of the percent oil extraction indicated (Table 2) highest percent oil being extracted $(28.83 \%$ and $24.07 \%)$ with chloroform followed by $n$-hexane $(21.29 \%$ and $19.29 \%)$ and petroleum ether (14.76 and $12.38 \%$ ) for both of the hybrids respectively. The data also indicated that conventional hybrid (FH-942) had comparatively higher percent oil content as compared to biotech hybrid (MNH-886). Physiochemical properties of both crude oils showed moisture content $1.35 \%$ in conventional variety and $(2.39 \%)$ in biotech variety (75 and 63), density (1.046 $\mathrm{gm} / \mathrm{ml}$ and $1.119 \mathrm{~g} / \mathrm{ml}$ ), specific gravity (0.981 and 1.043), and refractive index (1.467 and 1.468) of both varieties were almost similar with slight higher values for the conventional variety. Crude oil of conventional variety had a reddish brown color while BT variety had a dark yellowish -to orange oil. Iodine value of conventional hybrids oil was 101.2 while biotech hybrid had an iodine value of 95.2. Saponification value of the conventional variety's oil was 189.28 (mg of $\mathrm{KOH} / \mathrm{g}$ 
Oil) and that of BT variety was 175.30 (mg of $\mathrm{KOH} / \mathrm{g}$ oil). Both of oil samples had zero peroxide value free fatty acid value was 2.086 and 1.579 and total acid number was 4.1 and 3.1 for both the varieties respectively signifying the oil has edibility and less chances of getting rancid steadily.

Results of the fatty acid composition of the oils from the two gossypium, genotypes showed (Table 3, Figures 1 \& 2) insignificant differences. The only differences found were in the oleic acid concentrations which were quite high in the conventional variety as compared to the $\mathrm{Bt}$ variety. The $\mathrm{Bt}$ Variety however contained much higher proportions of linoleic, linolenic acids and arachidic acid. The data showed that when the fatty acids were pooled for the estimation of percent unsaturated and saturated fatty acids and the ratio of 16 carbons containing fatty acids to 18 carbon fatty acids the differences between the two genotypes were non-significant.

Results of the antibacterial assay showed (Table 4) that oil sample of conventional variety had higher activity against staphylococcus $(18 \mathrm{~mm})$ followed by Bacillus subtilis (16 $\mathrm{mm}$ ) as compared to Biotech sample which showed no resistance against staphylococcus, $12 \mathrm{~mm}$ against Bacillus subtilis and 10mm against klebsiella pneumonia respectively. As far the antifungal potential (Table 5)of the oils conventional variety showed excellent activity as compared to the biotech variety against Aspergillus flavus (105 $\mathrm{mm}$ and 90mm) followed by Aspergillus Niger $(95 \mathrm{~mm}$ and $85 \mathrm{~mm})$, and Alternaria Solania (80 and $70 \mathrm{~mm}$ ) respectively as against the standard DMSO.

The results of the antioxidant potential of the oil samples (Table 6) showed maximum free radical scavenging effect were demonstrated by the conventional oil having 20.88, 20.50, 19.37, 17.86, 16.86 and $13.96 \%$ at the tested doses of 100,80 , $60,40,20$ and $10 \mathrm{ppm}$ respectively. Biotech hybrids oil showed lesser potential $11.57,11.59,9.59,9.11,8.39$, and $6.59 \%$ at test doses of 100, 80, 60, 40, 20, and 10 ppm respectively. However both of the oils showed low antioxidant activity as compared to Quercetin as a standard.

Table 2. Physiochemical properties of crude oils of Gossypium hirsutum

\begin{tabular}{|c|c|c|c|}
\hline S. No & Physicochemical Properties & FH-942 & MNH-886 \\
\hline 1. & i-Pet. Ether & $14.76 \pm 0.08$ & $12.38 \pm 1.12$ \\
\hline & ii- N. Hexane & $21.29 \pm 0.02$ & $19.29 \pm 0.53$ \\
\hline & iii-Chloroform & $28.83 \pm 0.21$ & $24.07 \pm 0.08$ \\
\hline & Moisture $(\%)$ & $1.35 \pm 0.02$ & $2.39 \pm 0.56$ \\
\hline 2. & Viscosity at $21^{\circ} \mathrm{C}(\%)$ & $75 \pm 0.03$ & $63 \pm 0.78$ \\
\hline 3. & Density $\left(20^{\circ} \mathrm{C} \mathrm{kg} / \mathrm{ml}\right)$ & $1.046 \pm 0.04$ & $1.119 \pm 0.04$ \\
\hline 4. & Specific Gravity $(\%)$ & $0.981 \pm 0.12$ & $1.043 \pm 0.03$ \\
\hline 5. & Refractive index at $25^{\circ} \mathrm{C}$ & $1.467 \pm 1.23$ & $1.468 \pm 0.91$ \\
\hline 6. & Color ( against light with eye sighting) & Reddish Brown & Dark Yellowish to \\
\hline 7. & Orange \\
\hline 8. & Saponification value $(\mathrm{mg}$ of $\mathrm{KOH} / \mathrm{g}$ of & $101.2 \pm 0.78$ & $95.2 \pm 1.02$ \\
\hline 9. & oil) & $189.28 \pm 0.03$ & $175.30 \pm 0.03$ \\
\hline 10 & Peroxide value $(\mathrm{MEq}$ of O2/kg of oil) & & 0 \\
\hline 11. & Free fatty acid value $(\mathrm{g} / 100 \mathrm{~g}$ of oil) & $2.086 \pm 0.91$ & $1.579 \pm 0.02$ \\
\hline
\end{tabular}


Table 3. Fatty acids profiles of the seed oils

\begin{tabular}{|c|c|c|c|}
\hline Fatty acids \% & FH-942 & MNH-886 & P Level \\
\hline C 10:0; Capric acid & $0.017 \pm 0.02$ & $0.01+0.15$ & 0.23 \\
\hline C 12:0; Lauric acid & $0.034 \pm 0.01$ & $0.04+0.05$ & 0.16 \\
\hline C 14:0; Myristic acid & $1.099 \pm 0.01$ & $1.18+0.03$ & 0.067 \\
\hline C 15:0; Pantadecanoic acid & $0.034 \pm 0.01$ & $0.03+0.11$ & 1.02 \\
\hline C 16:0; Palmitic acid & $24.670 \pm 0.17$ & $23.88+0.09$ & 0.23 \\
\hline C 16:1; Palmitoleic acid & $0.685 \pm 0.2$ & $0.72+0.61$ & 0.078 \\
\hline C 17:0; Margaric acid & $0.102 \pm 0.01$ & $0.09+0.11$ & $0.045^{*}$ \\
\hline C 18:0; Stearic acid & $3.222 \pm 0.04$ & $3.17+0.03$ & 0.067 \\
\hline C 18:1c; Oleic acid & $15.77 \pm 0.01$ & $12.34+0.01$ & $0.046^{*}$ \\
\hline C 18:1n9t; Elaidic acid & $1.17 \pm 0.01$ & $1.30+0.02$ & 0.068 \\
\hline C 18:2c; Linoleic acid & $46.69 \pm 0.12$ & $49.76+1.73$ & $0.049^{*}$ \\
\hline C 18:2t; Octadecadicnoic acid & $0.36 \pm 0.01$ & $0.33+0.02$ & 1.002 \\
\hline C 18:3n6; g-linolenic aicd & $5.67 \pm 0.02$ & $6.17+0.02$ & $0.052^{*}$ \\
\hline C 18:3n3; Linolenic acid & $0.34 \pm 0.05$ & $0.37+0.09$ & 0.91 \\
\hline C 20:0; Arachidicacic acid & $0.09 \pm 0.01$ & $0.37+0.03$ & $0.039^{*}$ \\
\hline C 22:0; Behenic acid & $0.017 \pm 0.02$ & $0.12+0.01$ & 0.061 \\
\hline C 23:0; Tricosanoic acid & $0.051 \pm 0.02$ & $0.03+0.02$ & 0.071 \\
\hline C 24:0; Lignoceric acid & 0.098 & $0.56+0.09$ & 0.051 \\
\hline \% saturated & $29.38 \pm 0.03$ & $28.79+0.44$ & 0.068 \\
\hline \% unsaturated & $70.83 \pm 0.012$ & $70.68+0.09$ & 0.91 \\
\hline 18/16 ratio & $0.348 \pm 0.003$ & $0.33+0.25$ & 0.081 \\
\hline 20-24 ratio & $0.5 \pm 0.001$ & $0.58+0.02$ & 0.087 \\
\hline
\end{tabular}

*Differences are significant at $\mathrm{P} \leq 0.05$

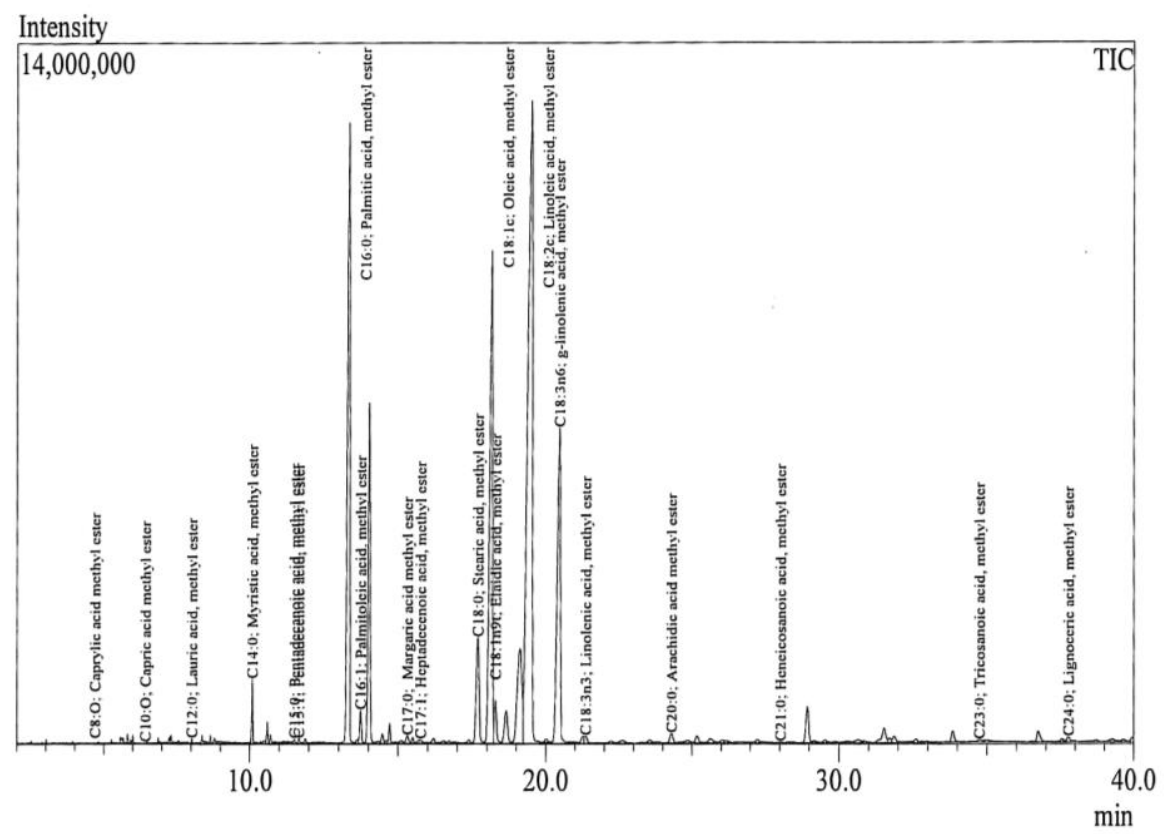

Figure 1. GC MS chromatogram of fatty acids for FH-942 


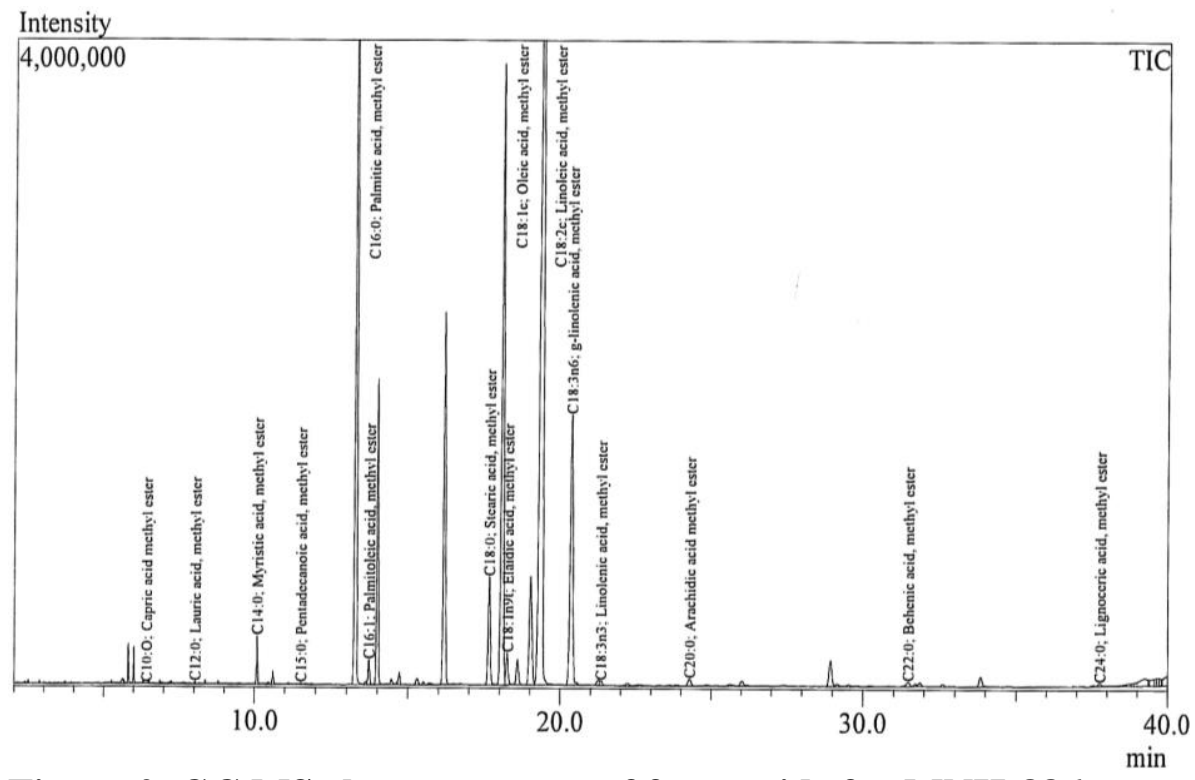

Figure 2. GC MS chromatogram of fatty acids for MNH-886

Table 4. Antibacterial assay of the oils of G. hirsutum

\begin{tabular}{|c|c|c|c|}
\hline \multirow{2}{*}{ Bacterial Strains } & \multicolumn{3}{|c|}{ Percent inhibition (mm) } \\
\cline { 2 - 4 } & FH-942 & MNH-886 & Streptomycin (2mg/ml) \\
\hline Bacillus subtilus & 16 & 12 & 28 \\
\hline Staphylococcus aureus & 18 & 0 & 30 \\
\hline Klebsiella pneumonia & 14 & 10 & 30 \\
\hline DMSO & 0 & 0 & 0 \\
\hline
\end{tabular}

Table 5. Antifungal activity of the oils extracted from G. hirsutum

\begin{tabular}{|c|c|c|c|}
\hline Fungi strain & \multicolumn{3}{|c|}{ Percent inhibition (mm) } \\
\hline & FH-942 & MNH-886 & $\begin{array}{c}\text { DMSO } \\
\text { (Standard) }\end{array}$ \\
\hline Aspergillus flavus & 105 & 90 & 115 \\
\hline Alternaria solania & 80 & 70 & 115 \\
\hline Aspergillus niger & 95 & 85 & 115 \\
\hline
\end{tabular}

Table 6. Antioxidant profile of the oil extracted from $G$. hirsutum

\begin{tabular}{|c|c|c|}
\hline Conc. $(\mathbf{p p m})$ & \multicolumn{2}{|c|}{ \% DDPH Inhibition } \\
\hline & FH-942 & MNH-886 \\
\hline 10 & $13.69 \pm 0.02$ & $6.95 \pm 0.02$ \\
\hline 20 & $10.86 \pm 0.02$ & $8.39 \pm 0.04$ \\
\hline 40 & $17.86 \pm 0.04$ & $9.11 \pm 0.04$ \\
\hline 60 & $19.37 \pm 0.01$ & $9.59 \pm 0.03$ \\
\hline 80 & $20.50 \pm 0.03$ & $11.59 \pm 0.05$ \\
\hline 100 & $20.88 \pm 0.02$ & $11.75 \pm 0.03$ \\
\hline Quercetin & $100 \pm 0.001$ & $100 \pm 0.002$ \\
\hline
\end{tabular}

\section{Discussion}

In the present study two samples of cotton seeds were initially studied for various physicochemical characteristics to identify the practical importance and provide basis for suitability and utility of Biotech hybrids seeds. The fixed oils obtained from $G$. hirsutum were extracted with 
three different solvents i.e. n- hexane, petroleum ether and chloroform. Oil extraction (Table 2) with the soxhlet method by using chloroform gave highest percent yield $(28.83 \%$ and $24.07 \%)$ from both varieties. This could be due to the increased ability of the solvent to overcome forces that bind lipids within the sample matrix [12]. The oil content of conventional hybrid with all the solvents was greater than that of the Biotech hybrid. Fixed oil yield of cotton seed in the preset was more than being reported in Nigeria which ranged $15.05-24 \%$. This difference in the yield might be attributed to the ecological/ environmental factors in which the respective varieties were grown [13]. Similarly, as reported variations in the oil yield are expected when oils are extracted with different solvents [14-16]. However, the percent oil values of the samples under this study fell well within the recommended standards for cotton seed oil [17].

The moisture content of conventional sample was low as compared to BT sample. Low moisture content increases the shelf life of the oil by preventing oxidation and rancidity [13]. The higher moisture content will assist in hydrolysis while low moisture content in oil have been reported to increase its storability and suitability to be preserved for a longer period $[12,13]$. The conventional seed oil was more viscose than its BT counterpart indicating longer chain lengths and the values were found to be closer to values in literature [18].

Specific gravity and density of conventional seed oil were less than the BT variety seed oils confirming that specific gravity less than 1 (one) means the substance will float on water [19]. The value 0.981 specific gravity is also closer to specific gravity of groundnut and neem seed oil [18]. Refractive index values of both the sampled oils (1.467 and 1.468) were in close agreement with values reported for soybean oil (1.466-1.470) and palm kernel (1.449-1.451). The high refractive index of these oils seems to confirm the high number of carbon atoms in their fatty acids and increase in the double bonds [19].

Iodine value of the BT hybrid seed oil was $95.2 \mathrm{~g} / 100 \mathrm{~g}$ and that for conventional hybrid's seed oil was $101.2 \mathrm{~g} / 100 \mathrm{~g}$. The values obtained are closer to that of pumpkin seed oil with an iodine value of 105.53/100g [13]. Iodine value above 100 indicates high proportion of instauration and suggests that the oil may be used as drying agent and as a cooking oil [19]. The zero peroxide oxide value of both the oil indicates the oil is stable and would not easily go rancid [1]. Saponification value of the conventional oil was $175.30 \mathrm{mg}$ $\mathrm{KOH} / \mathrm{g}$. Both of these values are lower than $213 \mathrm{mg} \mathrm{KoH} / \mathrm{g}$ in neem seed oil and coconut oil $253 \mathrm{mg} \mathrm{KoH} / \mathrm{g} \mathrm{[19].} \mathrm{This}$ indicates that these oils can be used in soap production [20]. Acid value of the sampled oils (Table 2) was found to be 4-1 and $3.1 \mathrm{mg}$ of $\mathrm{KoH} / \mathrm{g}$ of oil for conventional and BT varieties respectively. There values are lower than that of olive oil $(17 \mathrm{mg} \mathrm{KoH} / 1 \mathrm{~g})$ and peanut fat $(10.49 \mathrm{mg} \mathrm{KOH} / \mathrm{g})$ being reported [19]. Results of the current data show that the oil is edible and can stay for a long time without getting rancid readily. The fatty acid composition of both the oils were according to the standards for cotton seed oil and were at par with the composition of cottonseed oil from Turkey and Nigeria [22, 23]. The differences in the omega fatty acids might be attributed to the adaptability of the Bt variety to the local environment or as suggested might be due to the transcriptional technique adopted [24, 25].

Antioxidant potential of both oils (Table 6) as tested by DPPH radical scavenging activity showed low activity for both the oils $(22.88 \%--6.95 \%)$ in contrast to the standard [26]. Antibacterial essay against these bacterial strains (Bacillus Subtilus, Staphylococcus aureus, and klebsiella Pneumonia) showed 60-33\% lower resistance against standard of 
streptomycin. However both of oils showed maximum antifungal activities (aspergillus flavus, alaternaria solania, and aspergillus Niger) as tested against standard DMSO indicating the use of cotton seed oils as pharmaceutical fungicide [27, 28].

Proximate composition of the cakes showed conventional variety to be better nutritionally than the BT variety, however the differences were not significant so far. Cotton seed cake of both varieties contained appreciable amount of proteins (29.98 and $28.49 \mathrm{~g} / 100 \mathrm{~g}$ ) and crude fiber (11.79 and $15.84 \mathrm{~g} / 100 \mathrm{~g}$ ) ash (7.74-6.69\%) and fats (14.4-12.2g/100gm) suggesting it to be a potential source in the animals feed. The data suggest that nutrient composition of the whole seeds from both the genotypes were at par with the international standards for cottonseed [29, 30].

\section{Conclusion}

This study can be concluded on the facts that conventional variety of $G$. hirsutum possess better Physicochemical, antioxidant and antimicrobial potential of oils and nutritional composition of seed cakes, however the differences so far are not significant for the selected samples. The desirable characteristics indicate potential uses of cotton seeds as an edible oil, and have utility in the preparation of pharmaceutical products, soap making, cosmetic products and as an animal feed and protein fortification source in human food.

\section{Authors' contributions}

Conceived and designed the experiments: F Ghaffar, I Khan \& H Shah, Performed the experiments: F Ghaffar \& K Iqbal, Analyzed the data: F Ghaffar, Contributed materials/ analysis/ tools: H Shah, Wrote the paper: F Ghaffar \& I Khan.

\section{References}

1. Jonathan F, Wendel JF, Brubaker C, Alvarez I, Cronn R \& Stewart MJ (2009). Evolution and Natural History of the Cotton Genus. In Andrew H. Paterson (Ed.). Genetics and Genomics of Cotton.
Plant Genetics and Genomics: Crops and Models 3: 3-22.

2. Ahmad M \& Salim M (2014). Oilseed: Problems and potentials. Retrieved http://www.pakissan.com/english/allabout/ crop/cotton/index.shtml

3. Chapman KD, Austin-Brown S, Spacace SA, Kinney AJ, Ripp KG, Pirtle IL \& Pirtle RM (2001). Transgenic cotton plants with increased seed oleic acid content. $J$ Am Oil Chem Soc 78: 941-947.

4. Clive J (2013). Global Status of Commercialized Biotech/GM Crops: Biotech Facts \& Trends. ISAAA Brief No.44. I Lhasa, New York Retrieved https://www.isaaa.org/

5. Liu QL, Singh SP \& Green AG (2002). High-stearic and high-oleic cottonseed oils produced by hairpin RNA-mediated posttranscriptional gene silencing. Plant Physiol 129: 1732-1743.

6. Lukong E, Labuschagne MT \& Hugo A (2007). The evaluation of oil and fatty acid composition in seed of cotton accessions from various countries. J Sci Food Agric 87: 340-347.

7. Skaria BP (2007). Aromatic Plant: Horticulture science series. Vol 1: New Indian Publishing. Retrieved www.hec.gov.pk/digitallibrary

8. American Oil Chemists' Society (1998). Official Method Ce 1e-91. pp. 3. In D. Firestone (Ed). Official Methods and Recommended Practices of the AOCS, 5th ed. AOCS Press, Champaign, IL.

9. AOAC Official Methods of Analyses (1990). Washington, Association of Official Analytical Chemists, DC. Retrieved https://law.resource.org/pub/us/cfr/ibr/002/ aoac.methods.1.1990.pdf

10. AOAC Official Methods of Analyses (2005). 15th Ed., Association of Official Analytical Chemists, Washington, DC. Retrieved https://www.fda.gov/ucm/groups/fdagovpublic/@fdagov-foods/ucm088702.pdf

11. Rauf A, Khan R \& Muhammad N (2013). Antioxidant studies of various solvent fractions and chemical constituents of Potentilla evestita. The Wolf African J of Pharmacy and Pharmacology 7(39): 2707-2710.

12. Makni M, Fetoui H, Garoui M, Garqouri NK, Iaber H, Makni J , Boudawara T \& 
Zeghal N (2010) Hypolipidemic and Hepato Protective Seeds Mixture Rich in Omega-3 and Omega-6 Fatty Acids. Food Chem Toxicology 48(8-9): 2239-46.

13. Agatemor C (2006). Studies of selected physicochemical properties of fluted pumpkin seed oil and topical almond seed oil. Pak J Nutr 5(4): 306-307.

14. Stansbury MF, Hoffpauir CL \& Hopper $\mathrm{TH}$ (1953). Influence of variety and environment on the iodine value of cottonseed oil. J Am Oil Chem Soc 30: 120-123.

15. Hamza MA, Abdel-Aal MH, \& Khalil MM (1988). Studies on Egyptian cottonseeds: Fatty acid-composition and protein patterns. Nahrung 32: 255-259.

16. Lawhon JT, Cater CM \& Mattil KF (1977). Evaluation of the food potential of sixteen varieties of cottonseed. $J \mathrm{Am}$ Oil Chem Soc 54: 75-80.

17. CODEX Alimentrius. Codex Standards for Fats and Oils from Vegetable Sources http://www.fao.org/docrep/004/y2774e/y2 774e04.htm

18. Mansor TST, Che Man YB, Shuhaimi M, Abdul Afiq MJ \& Kunorul FKM (2012). Physicochemical Properties Of Virgin Coconut Oil Extracted from Different Processing Methods. International Food Res J 19(3): 837-845.

19. Akhtar N, Adnan Q, Ahmad, M, Mehmood A \& Farzana, K (2009). Rheological studies and characterization of different oils. $J$ of the Chemical Society of Pak 31: 201-206.

20. Warra AA, Wawata IG, Gunus SY \& Anuara KM (2011) Extraction and physicochemical analysis of some selected northern Nigerian industrial oils. Archives of Appl Sci Res 3(4): 536-541

21. Nergiz C, Yalcin H, \& Yildiz H (1997). Some analytical characters of cottonseed varieties grown In Turkey. Grasas y Aceites 48(6): 411-414.

22. Adelola OB \& Ndudi EA (2012) Extraction \& Characterization of Cottonseed (Gossypium) Oil.
International $J$ of Basic \& Applied Sciences 1(2): 398-402.

23. Liu QL, Singh SP \& Green AG (2002). High-stearic and high-oleic cottonseed oils produced by hairpin RNA-mediated post-transcriptional gene silencing. Plant Physiol 129: 1732-1743.

24. Lukonge E, Labuschagne MT \& Hugo A (2007). The evaluation of oil and fatty acid composition in seed of cotton accessions from various countries. $J$ Sci Food Agric 87: 340-347.

25. Uddin G, Rauf A, Gul S, Saleem M, Umar S \& Khan A (2013) Proximate chemical composition and biological profile of fatty acids of Withania Somnofera L. J of Medicinal Plants Res 7(27): 034-2039.

26. Rauf A, Khan A, Rasoal S, Shah ZA, \& Saleem M (2012) Invitro antifungal activity of these selected Pakistani medicinal plants. Middle East $J$ of Medicinal Plants Res 1(2): 41-43.

27. Rahman IU, Barkatullah, Ibrar M \& Rauf A (2012) physicochemical characterization of fixed oils of Skimmia laureola and Zanthoxylum armatum. Middle East $J$ of Medicinal Plants Res 1(3): 51-58.

28. National Cottonseed Products Association (2000). Kansas State University Agricultural Experiment Station and Cooperative Extension Service Kansas State University Agricultural Experiment Station and Cooperative Extension Service. Retrieved https://www.feedipedia.org/node/550

29. Heuze V, Tran G, Hassoun P, Brossard L, Bastianelli D \& Lebas F (2015). Cotton Seeds. Feedipedia, a programme by INRA, CIRAD, AFZ \& FAO https:// www.feedeipedia.org/node/742.

30. Bellaloui N, Stetina SR \& Turley R (2015). Cottonseed protein, oil, and mineral status in near-isogenic Gossypium Hirsutum cotton lines expressing fuzzy / linted and fuzzles / linted seed phenotypes under field condition. Front Plant Sci 6: 137. 